\title{
The Role of Melatonin in Improving Clinical Responses of Chemotherapy in Solid Cancer Patients: A Systematic Review
}

Diani Kartini ${ }^{1 *}$, Sonar Soni Panigoro', Muchlis Ramli', Rianto Setiabudy ${ }^{2}$ and Akmal Taher ${ }^{3}$

${ }^{1}$ Oncology Division, Surgery Department, Cipto Mangunkusumo National Hospital, Jakarta, Indonesia

${ }^{2}$ Faculty of Medicine, Pharmacology and Therapeutics Department, Universitas Indonesia, Jakarta, Indonesia

${ }^{3}$ Urology Department, Cipto Mangunkusumo National Hospital, Jakarta, Indonesia

\begin{abstract}
Background: Melatonin is known as a potent antioxidant. It also has other roles in modulating immune system and inhibiting proliferation, depending on the dose given. This agent has been used widely as a supplementation in cancer patients. However, effect of this antioxidant towards the efficacy of various therapeutic modalities in cancer, including chemotherapy, remains unclear.
\end{abstract}

Objective: This systematic review aims to know effect of melatonin as an adjuvant therapy towards chemotherapy response in solid cancer patients.

Methods: We reviewed articles systematically from 8 databases including Pubmed, EBSCO, Cochrane, ClinicalKey, Proquest, ScienceDirect, Scopus, and Wiley Online Library. Keywords used in literature searching were cancer and all similar terms, melatonin, chemotherapy, and response. We used limitations to narrow the result. We included clinical trials that evaluated clinical response of chemotherapy in solid cancer patients. Studies were reviewed by two authors using OXFORD RCT appraisal sheets.

Results: The results showed improved clinical response associated with chemotherapy plus melatonin treatment. Two out of eight studies were not statistically significant $(p>0.05)$. There was high risk of bias in all of the studies regarding randomization process, allocation concealment, intention-to-treat principal, and blinding.

Conclusion: Melatonin has positive effect in improving chemotherapy response in solid cancer patients. Regarding the lack of methodological validation in prior studies, larger and well-designed studies are needed in the future.

Keywords: Melatonin; Cancer; Solid; Chemotherapy; Clinical response

\section{Introduction}

It is common for patient undergoing cancer treatment to consume any kind of supplement in order to enhance treatment efficacy or minimize side effects. There are many supplementations available out there including antioxidant which is used by approximately $22-83 \%$ cancer patients [1-3]. This group of antioxidant includes $\mathrm{N}$-acetylcysteine, glutathione, vitamin A, vitamin $\mathrm{C}$, vitamin $\mathrm{E}$, beta carotene, melatonin, and many others. The one which has been explored by many researchers is melatonin (MLT).

MLT is a hormone secreted by pineal gland. It is located deep inside brain near the hypothalamus. Production of melatonin, also known as "darkness hormone", is affected by light. Thus it is produced at night and works in controlling biological rhythm. Study in hamsters reported that pineal gland was activated after more than 13-hour-long of dark exposure. Light signals captured by eyes will be carried to the suprachiasma nucleus of the hypothalamus and then to the pineal gland, activating secretion of melatonin [4,5].

Until now, melatonin and its properties is still being investigated. Other than regulating sleep cycle, melatonin is believed to be a potent antioxidant [6-10]. Melatonin also has anticancer property by acting in several mechanisms. These include:

(1) Direct cytotoxic action by inducting apoptosis in cell expressing MLT-receptors,

(2) Stimulating immune response to control tumor activity,

(3) Modulating oncogene expression to decrease biological malignancy [8].
It is still a debate among researchers regarding effect of melatonin in cancer treatment, including chemotherapy [6,11]. Antioxidant effect of melatonin affected not only normal cells but also the malignant cells. In patients undergoing chemotherapy or radiation, which reactive oxygen species (ROS) is induced instead of suppressed, the efficacy may decrease [11]. In contrast, other literature revealed possibility of melatonin effect in reducing treatment side effect instead of decreasing efficacy as an antioxidant. This is in accordance with review by Chuffa evaluating melatonin in ovarian cancer. This study stated that antioxidant effect of melatonin prevents apoptosis in the healthy cells. While in cancer cells, melatonin prevents proliferation, angiogenesis, and also induces apoptosis and immune response at the same time [7]. Therefore, melatonin can be used to minimize side effects of chemotherapy and radiation without decreasing efficacy in killing cancer cells [12].

Regarding the debate about antioxidant effect of melatonin, we need further studies to make things clearer. This study will systematically review effects of melatonin as an adjuvant therapy towards chemotherapy in solid cancer patients.

${ }^{*}$ Corresponding author: Diani Kartini, Oncology Division, Surgery Department, Cipto Mangunkusumo National Hospital, Jakarta, Indonesia, Tel: +628122684919; E-mail: d.kartini@gmail.com

Received January 05, 2019; Accepted January 23, 2019; Published January 25, 2019 Citation: Kartini D, Panigoro SS, Ramli M, Setiabudy R, Taher A (2019) The Role of Melatonin in Improving Clinical Responses of Chemotherapy in Solid Cancer Patients: A Systematic Review. J Cancer Sci Ther 11: 020-024. doi: 10.4172/19485956.1000577

Copyright: (c) 2019 Kartini D, et al. This is an open-access article distributed under the terms of the Creative Commons Attribution License, which permits unrestricted use, distribution, and reproduction in any medium, provided the original author and source are credited. 


\section{Literatur Review}

We start this study by specifying the clinical question (PICO) [13]. Characteristics of patients $(\mathrm{P})$ in our inclusion criteria is solid cancer patients (excluding lymphoma or hematological malignancy). There is no specific limitation regarding patients' characteristics. Intervention (I) and comparison (C) that will be evaluated are chemotherapy given with melatonin and chemotherapy only, respectively. Any kinds of treatment given other than mentioned earlier will be considered as exclusion criteria. Outcome (O) in this study is chemotherapy responses. Chemotherapy responses is an objective measure which can be evaluated with specific tool, The WHO criteria or Response Evaluation Criteria in Solid Tumors Group (RECIST). Complete and partial responses will be considered as expected or positive response, while stable and progressive disease will be considered otherwise. Any study not mentioning chemotherapy responses as the outcome will be excluded. We included trials, observational studies, systematic reviews, and meta-analyses.

Literature searching was done online in August 2018 from eight databases (Pubmed, EBSCO (1950-present), Cochrane, ClinicalKey,
Proquest (1950-present), ScienceDirect, Scopus, and Wiley Online Library). We used MesH feature in several databases to cover any term of cancer authors used in their articles. To assure that study done in human and not literature review or in vitro study, we used limitation.

We used this keywords in literature searching: neoplasm, cancer, tumor, carcinoma, melatonin, chemotherapy and response. For example, in PubMed, we used these keywords with Mesh feature and limitation: "Neoplasms"[Mesh] AND melatonin [Title/Abstract]) and chemotherapy [Title/Abstract] AND response [Title/Abstract]. Keywords used were not too specific in order to widen article options, enabling articles with chemotherapy response as secondary outcome were covered in this searching. However, we managed the setting so that the keywords were found in title or abstract. We also used filter such as human, clinical trial, observational study and systematic review.

Eligibility assessment was done by two reviewers independently. Review author assessed the title and abstract then decided whether the study was suitable for further review. Full text of selected studies were reviewed. Appraisal of study was done using OXFORD RCT Appraisal Sheet. For all included studies, we used Cochrane's Risk of Bias

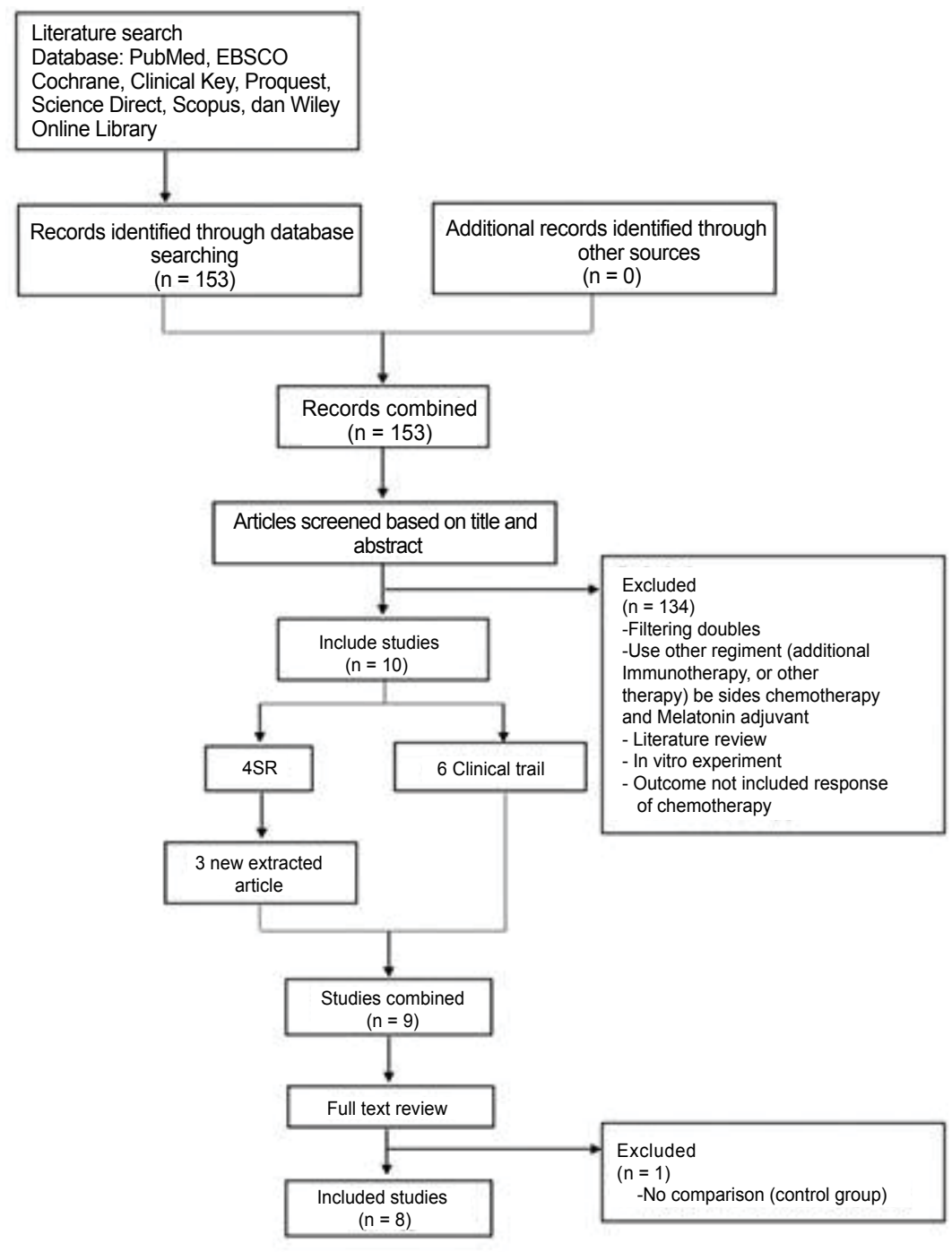

Figure 1: Study selection flowchart. 
Assessment Tool to assess risk of bias. This tool graded the studies risk of bias regarding their quality of randomization, blinding, intention to treat principle and others specified in the result section below. We contacted the authors of selected studies to complete missing data.

Data collected from each study were patient characteristics (type or location of cancer, stage, performance status), details of intervention (type of chemotherapy, dosage of melatonin, administration frequency), and chemotherapy responses as outcome. For the risk of bias we used Cochrane risk of bias tool. Chemotherapy response risk ratio (RR) or odds ratio (OR) were used as outcome measurement value.

\section{Results}

After getting 153 articles from the initial search in 8 databases, we screened the titles and abstracts. At the initial screening there were not many articles that matched the clinical questions of this study. From selected articles, there are also many of the same articles from the eight databases. In addition, in several databases such as Cochrane, ClinicalKey, Scopus and Wiley Online Library, the results of the selected articles were nil. After screening for eligibility, 10 studies were selected for a further evaluation The articles consisted of four systematic reviews (SR) and meta-analysis, as well as six trials. After reading full-text of the SRs, we obtained only part of the articles in the SR that is in accordance with the PICO of this study. We decided to identify the article in the appropriate SR then adjusted it to the other six articles found. At the end there were 8 articles evaluable in the appraisal stage. The eight studies included in this study (Table 1 and Figure 1).
The size of each study is different, the smallest in Cerea 2003 with 30 patients and the largest in Lissoni 2007 with 370 patients. The inclusion criteria for patients in the included study were patients with solid cancers. Solid cancer in these included studies include breast, lung, gastrointestinal, colorectal, and others. The clinical conditions of patients included in the inclusion criteria in each study were patients with poor, aggressive, and metastatic clinical status. The intervention carried out in each study was the combination of MLT for chemotherapy of solid cancer patients. The MLT dose given at all included studies was $20 \mathrm{mg} /$ day in the evening.

Comparison in the included study were patients given chemotherapy+MLT versus chemotherapy only. The aggregate of subjects from those studies were 595 patients in chemotherapy+MLT group and 655 patients in the chemotherapy only group. Outcomes reviewed in each study is in accordance to WHO criteria of clinical response of chemotherapy. The classification of responses in each study is different. There are those who reviewed the response on Complete Response (CR) and Partial Response (PR) only. But some differentiate the diseases as CR, PR, Stable disease (SD), and Progressive Disease (PD). According to WHO terminology, complete response (CR) was defined as a complete regression of all neoplastic lesions for at least 1 month; partial response (PR) was defined as a reduction of at least $50 \%$ in the first month. In addition to the response criteria, in several included studies the survival rate of patients in each group was also calculated. Characteristics of included studies are presented in Table 1.

Regarding biases, there are several things that can be done to minimize bias. By using Cochrane's Risk of Bias Assessment,

\begin{tabular}{|c|c|c|c|c|c|c|c|}
\hline Study author & Type of study & Subject & \begin{tabular}{|c|} 
Performance status \\
(Karnofsky Score)
\end{tabular} & $\begin{array}{c}\text { Intervention } \\
\text { (n) }\end{array}$ & $\begin{array}{c}\text { MLT dose }(\mathrm{mg} / \mathrm{d}) \\
\text { and duration }\end{array}$ & $\begin{array}{l}\text { Control } \\
\text { (n) }\end{array}$ & Outcome \\
\hline $\begin{array}{l}\text { Lissoni et al. } \\
\quad(1997)\end{array}$ & $\begin{array}{l}\text { Randomized } \\
\text { controlled trial }\end{array}$ & $\begin{array}{l}\text { Metastatic solid tumors in } \\
\text { poor clinical status (lung, } \\
\text { breast, gastrointestinal tract } \\
\text { tumor) }\end{array}$ & 70 & $\begin{array}{l}\mathrm{MLT}+\mathrm{CT} \\
\quad(39)\end{array}$ & $\begin{array}{c}20, \text { take with } \\
\text { chemo till disease } \\
\text { progression }\end{array}$ & $\begin{array}{l}\text { CT only } \\
\text { (41) }\end{array}$ & $\begin{array}{l}\text { The objective tumor regression } \\
\text { rate (CR+PR) was higher in } \\
\text { patients concomitantly treated } \\
\text { with } M L T \text { than in those } \\
\text { who received chemotherapy } \\
\text { alone, but the differences } \\
\text { were not significant. }\end{array}$ \\
\hline $\begin{array}{l}\text { Lissoni et al. } \\
\quad(1997)\end{array}$ & $\begin{array}{l}\text { Randomized } \\
\text { controlled trial }\end{array}$ & $\begin{array}{l}\text { Untreated advanced NSCLC, } \\
\text { unable to tolerate most } \\
\text { aggressive polychemotherapy }\end{array}$ & 80 & $\begin{array}{l}\mathrm{MLT}+\mathrm{CT} \\
(34)\end{array}$ & $\begin{array}{c}20, \text { take with } \\
\text { chemo till disease } \\
\text { progression }\end{array}$ & $\begin{array}{l}\text { CT only } \\
\text { (36) }\end{array}$ & $\begin{array}{c}\mathrm{CR}+\mathrm{PR}=11 / 33 \text { vs. } 6 / 36 \\
\mathrm{RR}=2.00, \mathrm{P}=1.09 \\
\mathrm{Cl}[0.83,4.80]\end{array}$ \\
\hline $\begin{array}{l}\text { Lissoni et al. } \\
\quad(1999)\end{array}$ & $\begin{array}{l}\text { Randomized } \\
\text { controlled trial }\end{array}$ & $\begin{array}{c}\text { Metastatic solid tumors } \\
\text { (NSCLC, breast, } \\
\text { gastrointestinal tract, head } \\
\text { and neck) with poor clinical } \\
\text { status }\end{array}$ & 80 & $\begin{array}{l}\mathrm{MLT}+\mathrm{CT} \\
\quad(124)\end{array}$ & $\begin{array}{l}20,1 \text { week } \\
\text { before the cycle } \\
\text { till disease } \\
\text { progression }\end{array}$ & $\begin{array}{l}\text { CT only } \\
(126)\end{array}$ & $\begin{array}{c}\mathrm{CR}+\mathrm{PR}=42 / 124 \text { vs. } 19 / 126 \\
\mathrm{RR}=2.25, \mathrm{p}<0.001 \mathrm{Cl}[1.39 \\
3.64]\end{array}$ \\
\hline $\begin{array}{l}\text { Lissoni } \\
(2002)\end{array}$ & $\begin{array}{l}\text { Randomized } \\
\text { controlled trial }\end{array}$ & $\begin{array}{l}\text { Untreated metastatic solid } \\
\text { tumor with chemotherapy- } \\
\text { resistant cancer and good } \\
\text { clinical status }\end{array}$ & 100 & $\begin{array}{l}\mathrm{MLT}+\mathrm{CT} \\
\quad(98)\end{array}$ & $\begin{array}{l}20, \text { few days } \\
\text { before the cycle } \\
\text { till disease } \\
\text { progression }\end{array}$ & $\begin{array}{l}\text { CT only } \\
(102)\end{array}$ & $\begin{array}{c}C R+P R=32 / 98 \text { vs. } 20 / 102 \\
R R=1.67, p<0.05 \\
C l[1.03,2.07]\end{array}$ \\
\hline $\begin{array}{l}\text { Lissoni et al. } \\
\qquad(2003)\end{array}$ & $\begin{array}{l}\text { Randomized } \\
\text { controlled trial }\end{array}$ & Untreated metastatic NSCLC & 100 & $\begin{array}{l}\mathrm{MLT}+\mathrm{CT} \\
\quad(49)\end{array}$ & $\begin{array}{l}20,1 \text { week } \\
\text { before the cycle } \\
\text { till disease } \\
\text { progression }\end{array}$ & $\begin{array}{l}\text { CT only } \\
\text { (51) }\end{array}$ & $\begin{array}{c}C R+P R=17 / 49 \text { vs. } 9 / 51 \\
R R=1.97, p<0.05 \\
C l[0.97,3.98]\end{array}$ \\
\hline $\begin{array}{l}\text { Cerea et al. } \\
\qquad(2003)\end{array}$ & $\begin{array}{l}\text { Randomized } \\
\text { controlled trial }\end{array}$ & $\begin{array}{l}\text { metastatic colorectal } \\
\text { patient }\end{array}$ & 90 & $\begin{array}{l}\mathrm{MLT}+\mathrm{CT} \\
(14)\end{array}$ & $\begin{array}{c}20,1 \text { week } \\
\text { before the cycle } \\
\text { till disease } \\
\text { progression }\end{array}$ & $\begin{array}{l}\text { CT only } \\
\text { (16) }\end{array}$ & $\begin{array}{c}\mathrm{CP}+\mathrm{PR}=5 / 14 \text { vs. } 2 / 16 \\
\mathrm{RR}=2.86, \mathrm{p}<0,05 \\
\mathrm{Cl}[0.65,12.48]\end{array}$ \\
\hline $\begin{array}{l}\text { Lissoni et al. } \\
\qquad(2007)\end{array}$ & $\begin{array}{l}\text { Randomized } \\
\text { controlled trial }\end{array}$ & $\begin{array}{l}\text { Metastatic NSCLC or } \\
\text { gastrointestinal }\end{array}$ & NA & $\begin{array}{l}\mathrm{MLT}+\mathrm{CT} \\
\quad(187)\end{array}$ & $\begin{array}{c}20,1 \text { week } \\
\text { before the cycle } \\
\text { till disease } \\
\text { progression }\end{array}$ & $\begin{array}{l}\text { CT only } \\
(183)\end{array}$ & $\begin{array}{c}\mathrm{CR}+\mathrm{PR}=68 / 187 \text { vs. } 37 / 183 \\
\mathrm{RR}=1.8, \mathrm{p}<0.01 \\
\mathrm{Cl}[1.27,2.54]\end{array}$ \\
\hline $\begin{array}{l}\text { Messina et al. } \\
(2010)\end{array}$ & $\begin{array}{l}\text { Non- } \\
\text { randomized } \\
\text { controlled trial }\end{array}$ & Metastatic NSCLC & 90 & $\begin{array}{l}\mathrm{MLT}+\mathrm{CT} \\
\quad(50)\end{array}$ & $\begin{array}{c}20,1 \text { week } \\
\text { before the cycle } \\
\text { till disease } \\
\text { progression }\end{array}$ & CT only (100) & $\begin{array}{c}C R+P R=21 / 50 \text { vs. } 24 / 100 \\
R R=1.75, p<0.001 \\
C l[1.09,2.82]\end{array}$ \\
\hline
\end{tabular}

Table 1: Characteristic of studies 
Citation: Kartini D, Panigoro SS, Ramli M, Setiabudy R, Taher A (2019) The Role of Melatonin in Improving Clinical Responses of Chemotherapy in Solid Cancer Patients: A Systematic Review. J Cancer Sci Ther 11: 020-024. doi: 10.4172/1948-5956.1000577

\begin{tabular}{|c|c|c|c|c|c|c|c|}
\hline \multirow[b]{2}{*}{$\begin{array}{l}\text { Included } \\
\text { Studies }\end{array}$} & \multicolumn{7}{|c|}{ Risk of Bias } \\
\hline & $\begin{array}{c}\text { Random sequence } \\
\text { generation } \\
\text { (selection bias) }\end{array}$ & $\begin{array}{c}\text { Allocation } \\
\text { concealment } \\
\text { (selection bias) }\end{array}$ & $\begin{array}{c}\text { Blinding of participants } \\
\text { and personnel } \\
\text { (performance bias) }\end{array}$ & $\begin{array}{l}\text { Blinding of outcome } \\
\text { assessment } \\
\text { (performance bias) }\end{array}$ & $\begin{array}{l}\text { Incomplete } \\
\text { outcome data } \\
\text { (attrition bias) }\end{array}$ & $\begin{array}{c}\text { Selective } \\
\text { reporting } \\
\text { (reporting bias) }\end{array}$ & Other bias \\
\hline Lissoni (1997) & Low Risk & Low Risk & High Risk & High Risk & High Risk & High Risk & Unclear \\
\hline Lissoni (1997) & Low Risk & Low Risk & High Risk & High Risk & Low Risk & Unclear & Unclear \\
\hline Lissoni (1999) & Low Risk & Low Risk & High Risk & High Risk & Low Risk & Unclear & Low Risk \\
\hline Lissoni (2002) & Low Risk & Low Risk & High Risk & High Risk & Low Risk & Unclear & Unclear \\
\hline Lissoni (2003) & Low Risk & Low Risk & High Risk & High Risk & Low Risk & Unclear & Unclear \\
\hline Cerea (2003) & Low Risk & Low Risk & High Risk & High Risk & High Risk & Unclear & Unclear \\
\hline Lissoni (2007) & Low Risk & Unclear & High Risk & Unclear & Low Risk & Unclear & Unclear \\
\hline Messina (2010) & High Risk & Unclear & High Risk & High Risk & Low Risk & Unclear & Unclear \\
\hline
\end{tabular}

Table 2: Risk of bias

randomization and allocation concealment is done to control selection bias. Blinding is useful for controlling measurement/performance bias. Details of the risk of bias for each study is listed on the Table 2.

Result from each study is on the Table 2. CR and PR obtained the lowest RR in study Lissoni (2002) and the highest RR in the study Cerea (2003). One study from Lissoni 1997a did not have a clear result for the $\mathrm{CT}$ alone group, but they concluded tumor regression rate $(\mathrm{CR}+\mathrm{PR})$ was higher in patients treated with MLT than in those who received chemotherapy alone.

The result summary showed significant clinical responses associated with chemotherapy plus MLT. Although, from those included study, there are two of eight studies that has not significant result. They are studies from Lissoni 1997a and Lissoni 1997b. This overall result also influenced by biases, as the summary of risk of biases is high risk of bias.

\section{Discussion}

Aim of this systematic review is to evaluate effect of melatonin towards chemotherapy response in solid cancer patients. We reviewed 6 suitable studies from database searching. In addition, we reviewed 3 studies extracted from selected systematic review and meta-analysis. From total 8 studies, there is one study excluded. All of studies showed improved clinical response $(R R=1.67-2.25)$ with partial and complete response [8-16]. However, $2 / 8$ studies were not statistically significant $[14,15]$. We attempted to contact authors several times for months in order to complete missing data and received no response.

All selected studies were done by same group of authors at same center in Italy. They have several publications related to melatonin and are still exploring the benefits of this substance (Lissoni and colleagues). Those publications indeed showed consistent results that melatonin improves clinical response of chemotherapy in solid cancer patients. However, there is a need for further study in different population to support their previous result. In addition, those selected study from Lissoni and colleagues did not report clearly regarding their randomization method, allocation concealment, blinding and intention-to-treat principal resulting high risk of bias in all of the studies. We have contacted the respective authors and wait for response.

This review showed improved clinical response in patients treated with melatonin adjuvant to chemotherapy. This result is obtained in various types of advanced solid cancer including head \& neck, breast, lung, and gastrointestinal cancer. Patients were in relatively good clinical status since they had 70-100 Karnofsky score. The result is in accordance with findings by Block and Seely $[1,17]$. The two studies showed positive effect in cancer patients treated with chemotherapy and antioxidant, including melatonin. Block reported 2 out of 4 suitable studies statistically significant improving clinical response. Seely likewise, reported 7 out of 19 studies suitable with our clinical question. Their findings showed that melatonin may increase chemotherapy response while reduce side effect. Despite the conclusion they also reported high risk of bias from those paper by Lissoni and colleague. Study by Greenlee evaluating antioxidant supplementation in breast cancer revealed the opposite [18]. They using one suitable study concluded that evidence is not sufficient to provide conclusion on the antioxidant supplementation in breast cancer.

\section{Conclusion}

Based on the summarized findings from the selected articles, we concluded that melatonin showed positive effect in improving chemotherapy response in solid cancer patients. However, considering the lack of methodological validation in all of studies included, we recommend to make a larger and well-designed studies in the future.

\section{Materials Availability}

Data and materials included in this publication are available for further evaluation. Please contact the corresponding author to access the data and materials.

\section{Disclosure}

Authors has no conflict of interest regarding publication of this study.

\section{Funding Statement}

We received no funding support from any agencies in commercial, public, or nonprofit sectors for this publication.

\section{References}

1. Block KI, Koch AC, Mead MN, Tothy PK, Newman RA, et al. (2007) Impact of antioxidant supplementation on chemotherapeutic efficacy: A systematic review of the evidence from randomized controlled trials. Cancer Treat Rev 33: $407-418$

2. Molassiotis A, Ozden G, Platin N, Scott JA, Pud D, et al. (2006) Complementary and alternative medicine use in patients with head and neck cancers in Europe. Eur J Cancer Care 15: 19-24.

3. Richardson MA, Sanders T, Palmer JL, Greisinger A, Singletary SE (2000) Complementary/alternative medicine use in a comprehensive cancer center and the implications for oncology. J Clin Oncol 18: 2505-2514.

4. Guyton AC, Hall JE (2006) Textbook of medical physiology. Philadelphia Elsevier Saunders.

5. Silverthorn DU, Johnson BR, Ober WC, Garrison CW, Silverthorn AC (2010) Human physiology: An integrated approach: San Fransisco 2: 1.

6. Lawenda BD, Kelly KM, Ladas EJ, Sagar SM, Vickers A, et al. (2008) Should supplemental antioxidant administration be avoided during chemotherapy and radiation therapy?. J Natl Cancer Inst 100: 773-783. 
Citation: Kartini D, Panigoro SS, Ramli M, Setiabudy R, Taher A (2019) The Role of Melatonin in Improving Clinical Responses of Chemotherapy in Solid Cancer Patients: A Systematic Review. J Cancer Sci Ther 11: 020-024. doi: 10.4172/1948-5956.1000577

7. Chuffa LGA, Reiter RJ, Lupi LA (2017) Melatonin as a promising agent to treat ovarian cancer: Molecular mechanisms. Carcinogenesis 38: 945-952.

8. Lissoni $P$ (2006) Biochemotherapy with standard chemotherapies plus the pineal hormone melatonin in the treatment of advanced solid neoplasms. Pathol Biol 55: 201-204.

9. Lissoni $\mathrm{P}(2001)$ Is there a role for melatonin in supportive care?. Support Care Cancer 10: 110-116.

10. Lissoni P, Barni S, Mandala M, Ardizzoia A, Paolorossi F, et al. (1999) Decreased toxicity and increased efficacy of cancer chemotherapy using the pineal hormone melatonin in metastatic solid tumour patients with poor clinical status. Eur J Cancer 35: 1688-1692.

11. Conklin KA (2004) Cancer chemotherapy and antioxidants. J Nutr 134: 3201S-3204S.

12. Lissoni $P$, Chilelli M, Villa S, Cerizza L, Tancini G (2003) Five years survival in metastatic non-small cell lung cancer patients treated with chemotherapy alone or chemotherapy and melatonin: A randomized trial. J Pineal Res 35: 12-15.

13. Liberati A, Altman DG, Tetzlaff J, Mulrow C, Gotzsche PC, et al. (2009) The PRISMA statement for reporting systematic reviews and meta-analyses of studies that evaluate health care interventions: Explanation and elaboration. PLoS Med 6: 1-28.
14. Lissoni P, Paolorossi F, Ardizzoia A, Barni S, Chilelli M, et al. (1997) A randomized study of chemotherapy with cisplatin plus etoposide versus chemoendocrine therapy with cisplatin, etoposide and the pineal hormone melatonin as a first-line treatment of advanced non-small cell lung cancer patients in a poor clinical state. J Pineal Res 23: 15-19.

15. Lissoni P, Tancini G, Barni S, Paolorossi F, Ardizzoia A, et al. (1997) Treatment of cancer chemotherapy-induced toxicity with the pineal hormone melatonin Support Care Cancer 5: 126-129.

16. Messina G, Lissoni $P$, Marchiori P, Bartolacelli E, Brivio F, et al. (2010) Enhancement of the efficacy of cancer chemotherapy by the pineal hormone melatonin and its relation with the psychospiritual status of cancer patients. $J$ Res Med Sci 15: 225-228.

17. Seely D, Wu P, Fritz H, Kennedy DA, Tsui T, et al. (2012) Melatonin as adjuvant cancer care with and without chemotherapy: A systematic review and metaanalysis of randomized trials. Integr Cancer Ther 11: 293-303.

18. Greenlee H, Hershman DL, Jacobson JS (2009) Use of antioxidant supplements during breast cancer treatment: A comprehensive review. Breast Cancer Res Treat 115: 437-452. 